\title{
Automated Count
}

National Cancer Institute

\section{Source}

National Cancer Institute. Automated Count. NCI Thesaurus. Code C154794.

A technique to determine the number of entities, that employs a machine or device to automatically detect cells as they pass through the instrument's light path. 